\title{
The effect of share repurchases on corporate investment policies: The South African experience
}

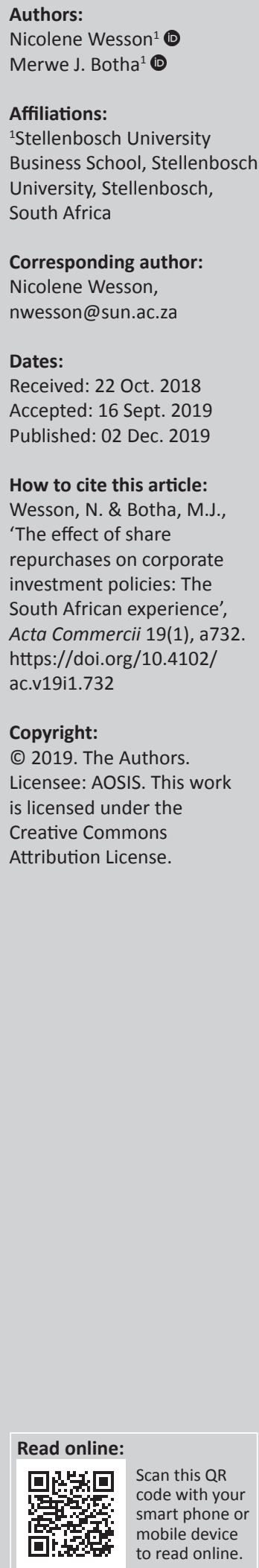

Orientation: The study analysed the investment behaviour of companies that enter into share repurchases.

Research purpose: The study examined the effect of share repurchases on corporate investment policies for companies listed on the Johannesburg Stock Exchange (JSE).

Motivation for the study: Empirical evidence suggests that companies repurchasing shares subsequently reduce their investment in employment, capital, and research and development. South Africa is a developing country with slow economic growth and high unemployment rates. Share repurchases have increased over time, but studies have not yet analysed the effect of share repurchases on investment policies in this country.

Research design, approach and method: The study applied a panel regression analysis technique to establish the effect of share repurchases on investment policies of JSE-listed companies. The sample comprised the 108 companies (listed in sectors other than basic materials and financials) that repurchased shares during the period 1999-2009.

Main findings: When growth opportunities are available, JSE-listed companies increase research and development expenditure.

Practical/managerial implications: The practical implication is that South African share repurchases should not be discouraged because companies repurchasing shares also increase their investment in future growth. The policy implication is that South African share repurchase regulations differ from global practice, which may affect the assessment of investment behaviour of companies that enter into share repurchases.

Contribution/value-add: Contradictory to global evidence, this study revealed that South African share repurchases have a positive effect on corporate investment policies. Investment and share repurchase behaviour may well be country-specific.

Keywords: share repurchase; share buy back; investment; employment; research and development.

\section{Introduction}

Share repurchases have the potential to erode future economic growth and reduce employment. Evidence suggests that increased share repurchase activity explains the lack of translation of corporate profitability (observed in the post-recession period) into growth in employment and overall economic prosperity (Lazonick 2014). Companies that repurchase shares tend subsequently to reduce their investment in employment, capital, and research and development (Almeida, Fos \& Kronlund 2016; Grullon \& Michaely 2004; Turco 2018; Van de Ven 2016).

When a company has excess cash, the cash can either be directed towards advancing business goals or returned to claim holders (through dividends, debt repayments or share repurchases). The amounts spent on share repurchases have increased dramatically over the past two decades and share repurchases have become the preferred payout method when compared to dividends (Wesson et al. 2018).

Share repurchases are generally motivated by the shareholder value creation benefit thereof, as observed in the increase in the share price and earnings per share (EPS) subsequent to share repurchase announcements (Ikenberry, Lakonishok \& Vermaelen 1995; Manconi, Peyer \& Vermaelen 2014), and the link between these short-term benefits and executive remuneration packages may well explain increased share repurchase activity (Hribar, Jenkins \& Johnson 2006; Lazonick 2014). Driving a shareholder value creation agenda is, however, not sustainable if the relationship between finance, the economy and society is not addressed as well (Lagoarde-Segot 2017). 
South Africa allowed share repurchases as from July 1999 and is relatively new to the share repurchase experience when compared to developed countries. South Africa has a dualistic economy, represented by - among others - a sophisticated stock exchange (the Johannesburg Stock Exchange [JSE]) comparable to those of the most advanced economies (Balcilar et al. 2016; World Bank 2014), within a developing economy with high unemployment rates and slow economic growth (Wesson et al. 2018). The translation of corporate profitability into societal economic welfare is a contentious topic in this country and understanding the consequences of share repurchases in the South African regulatory environment therefore carries particular significance.

The body of research into South African share repurchases is limited, mainly owing to the lack of comprehensive share repurchase data (Bester, Wesson \& Hamman 2010). Previous research has, however, confirmed that the South African share repurchase experience, in general, mirrors the global experience: Share repurchases have grown in popularity (Fortuin 2015; Vermeulen \& Yaffar 2014; Wesson, Bruwer \& Hamman 2015) and a positive share price reaction has been observed subsequent to share repurchase announcements (Bhana 2007; Wesson, Muller \& Ward 2014, 2017). Corporate payout behaviour by JSE-listed companies indicates that, although the value of dividends still exceeds share repurchase value, a decrease in the number of dividendpaying companies has been evident over time (Wesson et al. 2015). While substantially higher share repurchase activity is reported in developed countries when compared to developing countries (Manconi et al. 2014), more share repurchases occur in South Africa when compared to other developing countries, such as Brazil, India and China (Wesson et al. 2018).

To the best knowledge of the authors, no South African study has yet explored the impact of share repurchases on corporate investment policies to assess the effect of share repurchases on future economic growth and employment. The aim of the present study was to ascertain the effect of share repurchases on corporate investment policies - with investment in employment, capital investment, and research and development expenditure used as proxies for corporate investment policies. By comparing the share repurchase activities of South African companies to the trends in their investment policies, an assessment can be made on whether share repurchases are compromising long-term corporate and economic growth for short-term gains. The results of the present study will equip regulators and other stakeholders (including shareholders) in making informed decisions on the governance pertaining to share repurchases, as well as the effect of share repurchases on corporate profitability and economic prosperity.

\section{Literature review \\ Background}

The purpose of a company is not solely value creation for its shareholders but also the betterment of society at large
(Harrison \& Freeman 1999). Effective management of a company can be employed in a mutually beneficial way, where stakeholder management results in improved shareholder value (Hillman \& Keim 2001).

Shareholder value relates to the risks borne by shareholders (Rappaport 2006). The financial returns demanded by shareholders can be realised through capital growth or by the disbursement of cash dividends (Bender \& Ward 2008). Shareholder value is created when the return (capital growth plus dividend income) on shareholders' investments exceeds the expected rate of return (Richard \& Wilson 2012). Fundamentally, for shareholders, capital growth is realised when the market value of their shares increase. Increased market value can be derived through short-term increases in the share price or by long-term share price increases based on the underlying strength of the company's performance.

The payout decision of a company may have a short-term or a long-term impact on the share price. Dividend payments and share repurchases generally lead to short-term share price increases, with share repurchase returns usually outperforming dividend returns (Howe, He \& Kao 1992). Also, when companies use excess cash to invest in capital projects with high net present value opportunities, these investments ultimately lead to long-term capital growth (Bradford De Long \& Summers 1991; Sualehkhattak \& Hussain 2017).

Long-term capital growth is to the benefit of not only the shareholders but also other stakeholders of the company. Improved company performance translates to the economy as a whole and generally allows companies to increase employment numbers and to reward employees in a financial sense (through competitive salaries and bonuses), as well as in a non-monetary sense (through job security and career development) (Ul Haq 2012). Increased capital investment in general leads to an increase in economic growth (Bradford De Long \& Summers 1991; Kodongo \& Ojah 2016).

Does a company's decision to repurchase shares negatively affect the long-term growth of the company and the economy? Are companies using excess cash rather to fund share repurchases (and utilise the short-term benefits thereof), thereby maximising shareholder value at the expense of stakeholder value? Literature suggests that companies repurchasing shares do decrease their investments towards long-term growth, hence maximising shareholder value at the expense of stakeholder value (Almeida et al. 2016; Grullon \& Michaely 2004; Lazonick 2014; Turco 2018; Van de Ven 2016).

The present study explores whether share repurchase activities by JSE-listed companies affect corporate investment policies (with specific reference to investment in employment, capital investment, and research and development expenses). A discussion on the motivations for share repurchases, as well as the trends in share repurchase and investment activity, is therefore required to provide the necessary context to assess the effect of share repurchases on investment policy. 


\section{Share repurchase motivations}

The share repurchase phenomenon is seen as one of the most significant trends in corporate finance of the 1990s (Jagannathan, Stephens \& Weisbach 2000). The increased volume and value of share repurchases have raised concerns on what the real motivations for share repurchases are and whether these motives support corporate and economic growth.

The motivation for share repurchases mostly provided by repurchasing companies is that their shares are undervalued, hence the repurchasing company is seen as a 'good investment' (Chan et al. 2010; Tabtieng 2013; Wansley, Lane \& Sarkar 1989). Companies also frequently state the increased EPS to be derived by share repurchases as their motivation to repurchase shares (Chivaka et al. 2009). It is, however, contended that potentially contentious issues (where the reasons for share repurchases potentially affect the interests of multiple stakeholders) are seldom explicitly stated as motivations for share repurchases (Chivaka et al. 2009). Share repurchases may therefore be undertaken to mislead the market (by taking advantage of the information-signalling effect and EPS enhancement thereof) or to benefit executives holding share options (Balachandran, Chalmers \& Haman 2008; Fenn \& Liang 2001; Gumport 2007; Lazonick 2014).

Many studies have been conducted to ascertain the real motivation for share repurchases by testing the effect of share repurchases on the underlying assumptions related to motivations for share repurchases. Literature suggests that companies generally repurchase their shares when their shares are undervalued; when future growth opportunities are not available; to signal increased future performance; to enhance employee incentives; to mitigate the dilutive effect of share options; and to distribute excess capital (Almeida et al. 2016).

The present study does not address a specific share repurchase motivation but adds to the existing literature on the real effect of share repurchases on investment policies (based on employment, capital investment, and research and development).

When ascertaining the effect of share repurchases on capital investment, it is, however, important to identify whether alternative growth opportunities are available. It has been argued that, with no alternative growth opportunities, the repurchase of shares by undervalued companies reflect the optimal use of excess cash, thereby negating claims that these repurchases reduce economic growth: The reductions in investment would have occurred irrespective of the number of share repurchases (Almeida et al. 2016; Mauboussin 2006). Irrespective of the availability of alternative growth opportunities, companies, however, cannot expect to remain competitive in a range of advanced technological industries without continued investment in research and manufacturing capabilities (Lazonick 2014). It can also be argued that there are other participants in the economy (apart from shareholders), for example taxpayers and employees who bear the risk of investing without a guaranteed return, and they also have claims on profits that are at least as strong as shareholders' claims (Lazonick 2014).

\section{Trends in share repurchase and investment activity behaviour}

Share repurchases are not a new concept, with American share repurchases dating back to 1982 (Lazonick 2014). Since 2005, the United States of America (USA) share repurchase value (for listed companies excluding financials) exceeded dividend payments (Dittmar 2008). The financial crisis of 2008-2009 resulted in a temporary decrease in share repurchases, but since 2010 the popularity of share repurchases has again increased, showing record levels for the more recent periods (2014-2015). The popularity of share repurchases is also evident in non-USA countries, with the United Kingdom showing the next highest growth in share repurchase announcements (Kim, Schremper \& Varaiya 2004; Stonham 2002) and Japan making the highest number of open market share repurchase announcements during the period 1998-2008 (Manconi et al. 2014). On aggregate, the share repurchase value of non-USA companies was, however, almost seven times lower (at \$145 billion) compared to USA repurchases (at $\$ 950$ billion) during 2013 2014 (Bretell, Gaffen \& Rohde 2015; Van Rixtel \& Villegas 2015). Although South Africa only allowed share repurchases as from 1999, share repurchases were found to be a popular payout method for JSE-listed companies as from 2005, with aggregate share repurchase value for non-financial and nonresource JSE-listed companies amounting to R13 689 billion for the period 1999-2009 (Wesson et al. 2015).

The increasing trend in share repurchases has not gone unnoticed, with a growing awareness that companies could obtain better returns (for all stakeholders) when reinvesting their cash into growth projects (Ro 2014). Concerns have, however, been raised that the high levels of share repurchase and dividend payments leave very little room for investment. US companies listed on the Standard \& Poor's Index from 1981 until 2012 spent, on average, more on dividends and repurchases than the net income they generated (Lazonick 2014). Evidence suggests that employees are being laid off while companies are continuing with returning cash to shareholders via share repurchases (Garofalo 2011).

Spending on share repurchases was found to have outpaced investments in research and development and other forms of capital expenditure (Bretell et al. 2015). A study on nonfinancial listed companies in the USA showed that, for companies that repurchased shares and also reported on research and development expenditure, a decrease in research and development expenditure from $60 \%$ of net income in the 1990s to 50\% during the period 2009-2012 was evident (Bretell et al. 2015).

Grullon and Michaely (2004) concluded that the negative relationship between share repurchases and the level of capital investment (based on capital expenses and research and 
development expenses) could be explained by the decrease in growth opportunities evident in American repurchasing companies. Growth opportunities were measured by using systematic risk and the cost of capital, combined with cash flow, operating performance and capital investment, as proxies: All these variables showed a decline when comparing pre- and post-repurchase periods, thereby indicating a decrease in growth opportunities (Grullon \& Michaely 2004).

Almeida et al. (2016) reported a negative relationship between share repurchases and investment policy (based on investment in employment, capital investment, and research and development expenses) for USA-listed companies during the period 1988-2010. In their methodology, they controlled for available growth opportunities using company valuation (Q) and cash flows as control variables. Almeida et al. (2016) also extended their study to eliminate unobservable variations in growth opportunities, by applying a discontinuity regression analysis around the prerepurchases EPS surprise point. It was found that EPSmotivated share repurchases are negatively correlated with employment, as well as with capital investment and research and development expenses. It was concluded that corporate executives are willing to trade off employment and investments for share repurchases to allow them to achieve positive EPS surprises (Almeida et al. 2016). Turco (2018) and Van de Ven (2016) applied methodologies similar to Almeida et al. (2016) on USA publicly listed companies for the period 1980-2017 and 1980-2014, respectively, and confirmed the Almeida et al. (2016) results: A significant negative relationship was reported between share repurchases and levels of capital expenditure, employment and investment in research and development. Turco (2018) reported a stronger effect among larger companies, operating in non-competitive markets.

The present study aims to examine the effect of share repurchases on corporate investment policies of JSE-listed companies. It will therefore be ascertained whether the investment policies of JSE-listed companies entering into share repurchases mirror global practice. There are, however, aspects unique to the South African regulatory environment pertaining to share repurchases, which may affect the methodology applied and the results reported. Although South African share repurchase types in general mirror global practice (of open market, tender offers and private offers albeit applying terminologies like general repurchases, pro rata offers and other specific offers), the types of entities allowed to repurchase shares and the tax treatment of share repurchases (versus dividends) in the South African regulatory environment have affected the observed share repurchase behaviour. Specific repurchases (i.e. pro rata offers and other specific offers) were reported to be the preferred share repurchase type - as opposed to open market (or general) share repurchases being the outrightly favoured method globally - for JSE-listed companies during the period 1999-2009 (Wesson et al. 2015). All share repurchase activities are also not announced on a daily/weekly/monthly basis as in most countries - with the JSE Listings Requirements stipulating that open market (or general) share repurchases only need to be announced via the Security Exchange News Service (SENS) of the JSE once a 3\% cumulative threshold has been reached. Open market share repurchases below the 3\% threshold are therefore never announced and, in the event of a 3\% announcement, these announcements could relate to open market share repurchases affected in the previous year(s)/month(s)/week(s)/day(s) (Wesson et al. 2015).

\section{Methodology and data description Population}

The population for this study comprised companies listed on the main board (including all sectors except basic materials and financials) of the JSE for the period 1999-2009. The period of this study reflects the period covered in the first comprehensive share repurchase database compiled in South Africa, which has only recently become available (Wesson et al. 2015). Companies were included in the population provided that they had listed ordinary or N-class shares; the JSE was their primary listing; and at least 3 years of data were available. Delisted companies were included (up to the date of their delisting) to reduce survivorship bias. The basic materials and financials sectors were excluded, owing to their sector-specific differences: Companies in the resource sector generally follow commodity prices - rather than company-specific factors - and the financial sector is highly regulated (Bester 2008).

The total population comprised 227 companies, resembling 1861 company-year observations. A total of 114 (of the 227) companies repurchased shares (via general and specific repurchases) during 361 company-year observations. Owing to the fact that open market share repurchases are not announced in real time or on a comprehensive basis (owing to the $3 \%$ rule), company-year share repurchase observations were used for the purpose of this study.

After adjusting for missing data (mainly owing to the methodology requirement that data need to be available for the year prior to and subsequent to the year in which shares were repurchased), the final population comprised 211 companies of which 108 companies repurchased shares. The final population contained 1595 company-year observations of which 353 company-year observations were related to share repurchases. Statistical tests were performed on the 108 companies that repurchased shares in 353 company-year observations during the period 1999-2009.

\section{Definition of variables and data collection}

The variables related to the present study comprised share repurchases, proxies for investment policies and control variables to account for the variation in growth opportunities.

Comprehensive data on share repurchases by JSE-listed companies are not available in any commercial financial database. The data collection procedure on share repurchases, 
as explained by Wesson et al. (2015), was followed in this study. Data collection therefore entailed scrutinising the components of the annual report (mainly the directors' report, statement of financial position, statement of changes in equity, share capital note and the shareholders' analysis) and capturing details of the JSE SENS announcements on share repurchases, to be able to compile a reliable and comprehensive share repurchase database (Wesson et al. 2015). The IRESS database was used to retrieve annual reports (IRESS product called Library) and to extract SENS announcements (IRESS product called News).

For the purpose of this study, share repurchases refer to those share repurchases that resulted in a net cash effect for the group and therefore include shares repurchased by holding companies from existing shareholders (but excluding the repurchases of shares held by their subsidiaries) and shares repurchased by subsidiaries of the holding company.

Share repurchases were recorded at ratio-level as the absolute value of the annual repurchase, scaled by total assets lagging the repurchase period by 1 year, similar to the methodology followed by Almeida et al. (2016).

Equation 1 represents the rationale applied when measuring the share repurchases at ratio-level per company, where $t=0$ relates to the financial year in which at least one repurchase was made, and $\mathrm{Y}$ represents the annual share repurchase value:

Repurchase $_{i, t}=Y_{i, t} /(\text { assets })_{i, t-1}$

Three proxies for investment policies were applied in this study, namely: employment, capital investment, and research and development expenses - consistent with the proxies applied by Almeida et al. (2016). For the employment proxy, two variables were applied, namely number of employees (in line with the Almeida et al. 2016 methodology) and salaries and wages. Because of companies often not disclosing their number of employees, a second variable (salaries and wages) was added to address possible data limitations. The change in the outcome of each of the investment policy proxies was measured as the difference between the level of the outcome in the year subsequent to the share repurchase, compared to the year before the repurchase. The change in the outcome of each of the investment policy proxies was normalised by total assets as at the year prior to the share repurchase.
Equations 2 and 3 represent the rationale applied when measuring the change in investment policy per company, where $t=0$ relates to the financial year in which at least one repurchase was made, and $X$ represents the investment variable:

$\Delta X_{i, t}=X_{i, t+1}-X_{i, t-1}$

Investment outcome $_{i, t}=\Delta X_{i, t} /(\text { assets })_{i, t-1}$

All data on the investment variables were extracted from the IRESS database. The specific data lines (in IRESS), which were used to calculate each of the investment variables, are listed in Appendix 1, Panel A.

When controlling for variations in growth opportunities, it is difficult for those external to the company to assess investment and growth opportunities at the disposal of the company and hence it is commonplace to employ a number of variables to proxy for growth and investment opportunities (Adam \& Goyal 2008). Table 1 contains the seven control variables applied in this study, their definitions and the studies supporting the appropriateness thereof. The specific data lines that were used to calculate each of the control variables were all retrieved from the IRESS database, except for dividend payments (which were retrieved mainly from annual report disclosures, following the methodology of Wesson et al. 2015), and are listed in Appendix 1, Panel B.

Almeida et al. (2016) observed a stronger relationship between share repurchases and investment variables when adding cash flow and the $\mathrm{Q}$ ratio in their investment regressions. According to Adam and Goyal (2008), caution should be exercised when employing the Q ratio (Tobin's Q) as proxy for growth opportunities, as the measure is often also used as proxy for corporate performance, intangibles, the quality of management, agency problems and company value. These concerns were however disclaimed by Dybvig and Warachka (2015) who questioned the use of Tobin's Q as a measure of performance, stating that underinvestment leads to an artificially higher Tobin's Q. A Tobin's $Q$ ratio in excess of unity is indicative of growth opportunities, while the converse indicates the lack of growth opportunities (Evans \& Gentry 2003).

Examining the effects of growth opportunities on the systematic risk of companies, empirical evidence suggests that growth opportunities contribute significantly to the

TABLE 1: Summary of control variables as proxies for variations in growth opportunities.

\begin{tabular}{|c|c|c|}
\hline Control variable & Definition & Supporting literature \\
\hline Cash flow & (profit after interest and tax + depreciation) $/(\text { (assets) })_{t-1}$ & Almeida et al. (2016) \\
\hline Q ratio & $\begin{array}{l}\text { (total assets book value }- \text { total equity book value }+ \text { market } \\
\text { capitalisation) })_{t}(\text { total assets book value) })_{t}\end{array}$ & $\begin{array}{l}\text { Almeida et al. (2016); Danbolt et al. (2011); Dybvig and } \\
\text { Warachka (2015) }\end{array}$ \\
\hline Market-to-book equity ratio (MBE) & Market capitalisation/(total equity book value) ${ }_{t}$ & $\begin{array}{l}\text { Adam and Goyal (2008); Chung and Charoenwong (1991); } \\
\text { Frank and Goyal (2009); Johnson (2003) }\end{array}$ \\
\hline Dividend payout ratio $(\mathrm{D} / \mathrm{P})$ & Total dividends paid $/$ market capitalisation $_{t}$ & Danbolt et al. (2011) \\
\hline Excess value of firm (EVF) (\%) & $\begin{array}{l}\left((\text { market capitalisation - total equity book value })_{t} /\right. \\
\left.(\text { market capitalisation + total liabilities book value })_{t}\right) * 100\end{array}$ & Ottoo (2000) \\
\hline Excess value of equity (EVE) (\%) & $\begin{array}{l}\text { ((market capitalisation }- \text { total equity book value })_{t} / \\
\left.(\text { market capitalisation })_{t}\right) * 100\end{array}$ & Ottoo (2000) \\
\hline $\begin{array}{l}\text { Capital investment to property, plant and } \\
\text { equipment ratio (CAPEX/PPE) }\end{array}$ & $\begin{array}{l}\text { (capital investment)/(total book value of land and buildings }+ \\
\text { total book value of other fixed assets) }\end{array}$ & Adam and Goyal (2008) \\
\hline
\end{tabular}


market value of equity (Chung \& Charoenwong 1991; Sualehkhattak \& Hussain 2017). As such, the use of the market-to-book equity (MBE) ratio can provide meaningful insights into the variation in growth opportunities faced by companies (Wrońska-Bukalska, Kaźmierska-Jóźwiak \& Rozkovec 2018). Two concerns associated with the MBE ratio are the application thereof as proxy for other variables and its sensitivity to the capital structure (i.e. more debt inflates MBE) of companies (Adam \& Goyal 2008). Addressing the latter, it was demonstrated that increased leverage may in itself proxy for investment opportunities (Frank \& Goyal 2009). As the MBE ratio includes the present value of all future cash flows over the value of equity generated by existing assets, a ratio larger than unity would be indicative of growth opportunities (Johnson 2003).

Exploring the usefulness of eight variables used commonly to proxy for growth opportunities, Danbolt, Hirst and Jones (2011) found that dividend-based measures are superior in predicting the growth in sales, assets and equity. As it is generally accepted that growth companies compromise dividend disbursements for investment, Danbolt et al. (2011) proposed the use of dividend yield $(\mathrm{D} / \mathrm{P})$ as a proxy variable for growth opportunities. A negative correlation between the $\mathrm{D} / \mathrm{P}$ and growth opportunities is expected. For this reason, a negative relationship between the $\mathrm{D} / \mathrm{P}$ and investment outcome variables is also expected (Danbolt et al. 2011).

Ottoo (2000) presented insights into the valuation of growth opportunities and suggested two models to estimate the percentage of value attributable to growth opportunities, namely the excess value of the firm (EVF) and excess value of equity (EVE) models to estimate growth opportunities. Following Danbolt et al. (2011), both the EVF and EVE models suffered drawbacks similar to other market-to-book ratios (e.g. the MBE) proposed. Danbolt et al. (2011) argued that these market-to-book value derived measures are likely to overestimate the share of value derived from growth opportunities.

Despite being identified as a less robust measure of growth opportunities when compared to market-based measures, the capital investment to property, plant and equipment (CAPEX/PPE) ratio is used as a control variable (Adam \& Goyal 2008). The reason for its inclusion is its independence from other control variables proposed as the CAPEX/PPE ratio is based purely on financial data. It is argued that companies that invest more, acquire more opportunities relative to their assets - compared to companies that invest less (Adam \& Goyal 2008).

\section{Data analysis}

In ascertaining the impact of share repurchases on investment policies, the population of companies entering into share repurchases was examined. In accommodating the crosssectional and longitudinal dependencies in the study population, the selection of methodologies was carefully considered. Using the advanced analytics software packages,
Statistica and $\mathrm{R}$, the cross-sectional time-series analysis (i.e. panel regression analysis) methodology was identified as appropriate, with the investment outcome variable as the dependent variable (at continuous, ratio-level) and share repurchases as the independent variable.

Preceding the analyses, data distributions of the various identified variables were transformed using winsorisation, limiting the effect of outliers. Redundancy analyses were then applied to assess multicollinearity, by applying a tolerance level of 0.2. Control variables offering little additional information (namely, MBE, EVF and EVE) were discarded and four control variables (namely, cash flow, $\mathrm{Q}$ ratio, $\mathrm{D} / \mathrm{P}$ ratio and $\mathrm{CAPEX} / \mathrm{PPE}$ ratio) were therefore applied in the panel regression analyses.

Finally, the Breusch-Pagan test was employed to test for heteroscedasticity. Where the Breusch-Pagan test indicated conditional heteroscedasticity, Statistica (using the White method) corrected the original regression for heteroscedasticity (White 1984).

Equation 4 presents the ordinary least squares (OLS) equation that was applied to each investment outcome variable and is consistent with the OLS analyses performed by Almeida et al. (2016) on the effect of repurchases on investment outcomes.

Investment outcome $_{i, t}=$ alpha + beta $_{i}$ Repurchases $_{i, t}+$ controls $_{i, t}+$ error $_{i, t}$

The present study considered three investment outcome variables, namely employment, capital investment (CAPEX), and research and development (R\&D). Four investment outcome variables were identified, one for each CAPEX and $R \& D$, and two variables (namely, number of employees, and salaries and wages) for employment. A regression analysis was therefore performed on each of the four investmentoutcome-dependent variables.

Regression coefficients were interpreted based on their sign, and not in absolute terms. The significance of coefficients generated by the panel regression analyses were evaluated using $t$-statistics and the calculated probability ( $p$-value) for each coefficient. A $5 \%$ significance level $(p<0.05)$ was applied to determine significant relationships.

\section{Ethical considerations}

This article followed all ethical standards for research without direct contact with human or animal subjects.

\section{Empirical results and discussion Descriptive statistics}

Descriptive statistics (based on winsorised data) on the study population are included in Appendix 2. Figures 1-3 support the large standard deviation and variance between the mean and median of most of the reported variables, as observed in Appendix 2. Of the 114 companies that repurchased shares 
during the period, many companies executed share repurchases in only 1 or 2 years during the 11 years covered in the present study (Figure 1). The number of companies repurchasing shares per annum initially increased (till 2003) and then levelled off (Figure 2), whereas the share repurchase value showed a steep increase from 2005 to 2009 (Figure 3). Figures 2 and 3 start with the year 2000, as no share repurchases were executed during 1999. Share repurchase value was therefore determined by a relatively small number of companies making large share repurchases in the period 2005-2009. Wesson et al. (2015) concurred that the share

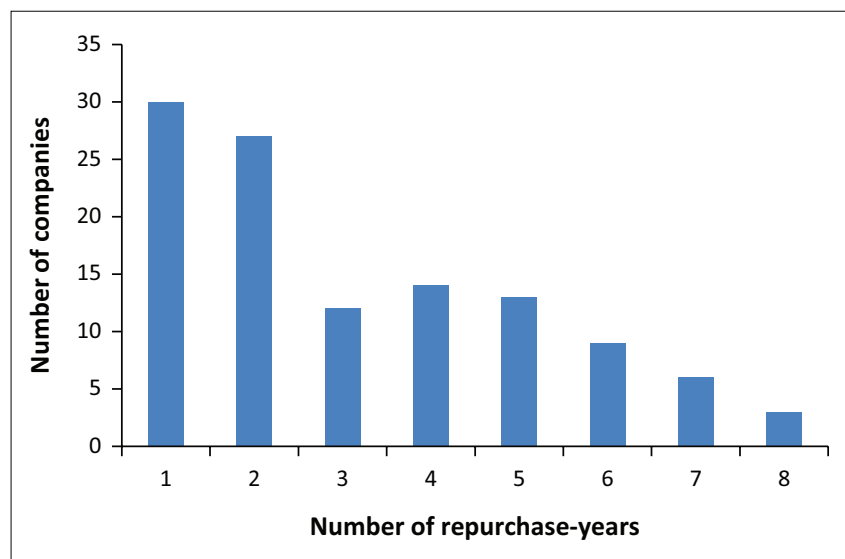

FIGURE 1: Frequency distribution of repurchase-years of the companies participating in repurchases.

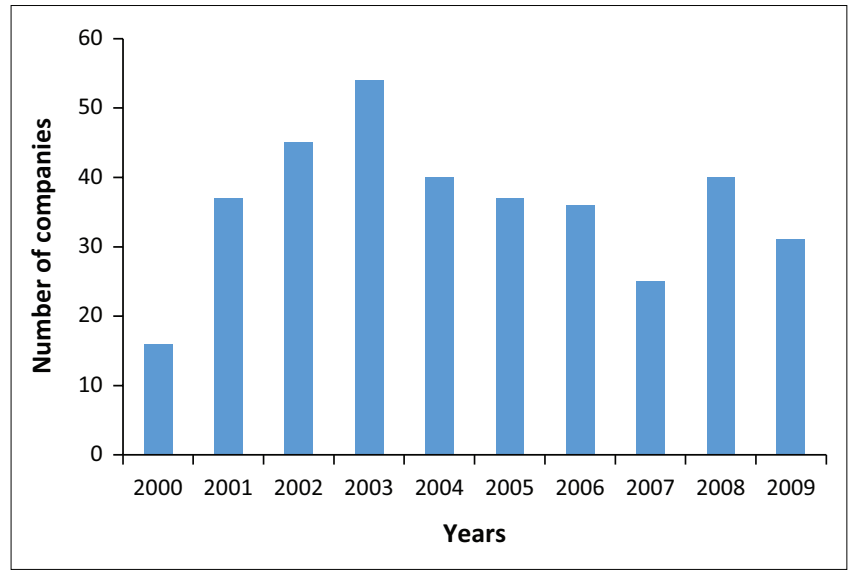

FIGURE 2: Frequency distribution of companies participating in repurchases.

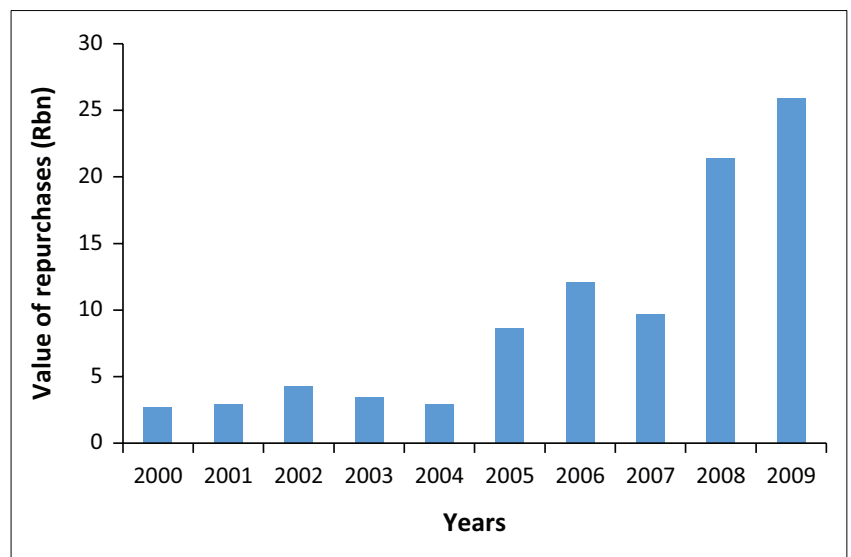

FIGURE 3: Value of repurchases per annum. repurchase value for the period 1999-2009 was mainly attributed to a small number of large capitalisation companies (Wesson et al. 2015).

The investment variables (employment, CAPEX and R\&D) show positive median values - suggesting increased investment by companies entering into share repurchases. The median of observed control variables indicate that JSE-listed companies entering into share repurchases may have available cash resources, and also pay dividends and maintain their fixed assets. The observed $Q$ ratio median (at a value below unity) may indicate that companies entering into share repurchases do not have growth opportunities available, as opposed to the positive MBE ratio median, indicating the availability of growth opportunities. The multivariate statistics (panel regression) will, however, confirm the relationship between share repurchases and investment policies, while controlling for available growth opportunities.

\section{Panel regression analyses}

Table 2 shows the results of the panel regressions and $t$-statistics based on the three investment outcomes (represented by four variables, namely employment per number of employees, employment per salaries and wages, CAPEX and R\&D). The share repurchases (independent variable) are depicted in Table 2, Panel A, while the control variables applied to control for variations in growth opportunities are depicted in Table 2, Panel B.

A negative, but not significant, relationship is observed between share repurchases and the employment (number of employees, and salaries and wages) and CAPEX investment outcomes (Table 2, Panel A). Johannesburg Stock Exchangelisted companies therefore invest less in employment and capital expenditure when also executing share repurchases. The reported negative relationships, although not significant, are consistent with literature - where significant negative relationships were reported with respect to employment and CAPEX investment outcomes (Almeida et al. 2016). The only significant relationship observed was found to be the positive relationship (significant at the $5 \%$ level) between share repurchases and the $R \& D$ investment outcome (Table 2, Panel A). The positive relationship between share repurchases and R\&D does, however, not resonate with literature, where a negative relationship between repurchase activity and R\&D was reported (Almeida et al. 2016). It may, however, indicate that JSE-listed companies entering into share repurchases regard increased investment in research and manufacturing capabilities as a necessity to remain competitive in the advanced technological age (Lazonick 2014).

In respect of the control variables (Table 2, Panel B), a significant positive relationship (at the $1 \%$ level of significance) was reported between cash flow and the employment (salaries and wages) investment outcome and the CAPEX investment outcome - which is in line with expectation, as a stronger cash flow position creates opportunities for investment and 
TABLE 2: Panel regression results, measuring the relationship between investment outcomes and share repurchases.

\begin{tabular}{|c|c|c|c|c|c|c|c|c|}
\hline \multirow[t]{3}{*}{ Variables } & \multicolumn{8}{|c|}{ Investment outcomes } \\
\hline & \multicolumn{2}{|c|}{$\begin{array}{c}\text { Employment } \\
\text { (number of employees) }\end{array}$} & \multicolumn{2}{|c|}{$\begin{array}{c}\text { Employment } \\
\text { (salaries and wages) }\end{array}$} & \multicolumn{2}{|c|}{ CAPEX } & \multicolumn{2}{|c|}{ R\&D } \\
\hline & Regression & $t$-statistics & Regression & $t$-statistics & Regression & $t$-statistics & Regression & $t$-statistics \\
\hline \multicolumn{9}{|c|}{ Panel A: Share repurchases } \\
\hline Share repurchases & -0.003 & -0.022 & -1.103 & -1.381 & -0.323 & -0.265 & $0.865 * *$ & 2.269 \\
\hline \multicolumn{9}{|c|}{ Panel B: Control variables } \\
\hline Cash flow & -1.095 & -1.086 & $40.243 * * *$ & 3.864 & $36.536 * * *$ & 2.717 & $-5.577^{*}$ & -1.764 \\
\hline Q ratio & 0.206 & 1.155 & $-1.730 *$ & -1.929 & -0.425 & -0.298 & 0.104 & 0.511 \\
\hline $\mathrm{D} / \mathrm{P}$ ratio & $-7.488 * * *$ & -2.563 & $-90.180 * * *$ & -3.421 & 18.479 & 0.379 & -10.030 & -1.641 \\
\hline CAPEX/PPE ratio & $0.145 * * *$ & 2.762 & 0.021 & 0.057 & 0.263 & 0.381 & $0.450 * * *$ & 3.044 \\
\hline
\end{tabular}

CAPEX, capital investment; CAPEX/PPE, capital investment to property, plant and equipment; R\&D, research and development.

$*, p<0.10 ; * *, p<0.05 ; * * *, p<0.01$.

increased employment remuneration. A significant positive relationship (at the $1 \%$ level of significance) was also reported between the CAPEX/PPE ratio and employment (number of employees) investment outcome and the R\&D investment outcome, indicating that companies that invest more also acquire more investment opportunities that require $R \& D$ expenses and also create employment opportunities (Adam \& Goyal 2008). A significant negative relationship (at the 1\% level of significance) was reported between the $\mathrm{D} / \mathrm{P}$ ratio and both employment investment outcomes which, consistent with literature, indicates a negative relationship between the $\mathrm{D} / \mathrm{P}$ ratio and growth opportunities - hence an inverse relationship between the D/P ratio and employment is expected (Danbolt et al. 2011; Gul 1998).

The results of the panel regressions therefore show that, when growth opportunities are available, share repurchases do not negatively affect investment policies of South African corporates. The only statistically significant results in terms of the relationship between share repurchases and investment policies in fact indicate that higher levels of $R \& D$ investment are associated with share repurchases. These findings are quite surprising, when compared to existing empirical evidence where statistically significant negative relationships were reported between share repurchases and investment policies. When growth opportunities are available, JSE-listed companies that enter into share repurchases therefore regard increased $R \& D$ investment as imperative in the advanced technological era. Investment into employment and capital are not significantly affected when JSE-listed companies enter into share repurchases.

It is, however, recognised that certain limitations pertaining to the present study may have affected the reported results. Firstly, South Africa implemented share repurchases as recently as in 1999 and the share repurchase experience has therefore only been part of the South African corporate landscape for a relatively short period (when compared to developed countries where earlier studies on investment policies have been performed). While the value of share repurchases by JSE-listed companies has steadily increased from 2005, share repurchases were dominated by a relatively small number of companies, with significant peaks in share repurchase data attributed to large market capitalisation companies performing large repurchases (Wesson et al. 2015). Illustrating the immaturity of repurchases in South Africa,
Wesson et al. (2015) found the disbursement of dividends to be the preferred mechanism of returning excess cash to shareholders. This contrasts with the trends in the USA where studies have found repurchases to be more popular than dividends in distributing cash to shareholders.

Secondly, the South African regulatory environment pertaining to the announcement of share repurchases (especially the 3\% rule on open market share repurchases) results in the exact date of share repurchase transactions not always being known. Hence, the methodology employed in the present study could not use quarterly data (as was employed by Almeida et al. 2016), but only annual data. The 2-year time period over which the change in investment variables was measured in the present study is therefore not entirely comparable with the methodology applied by Almeida et al. (2016).

Thirdly, the identification of variables to control for available growth opportunities is inherently difficult. Variation in growth opportunities may in fact be truly unobservable, with the selected control variables not accurately accounting for this variation. Even with the addition of control variables, the results may be subject to endogeneity concerns (Almeida et al. 2016). In the present study, the addition of control variables was allowed to address endogeneity concerns, but this strategy may not have been effective. Companies with poor growth opportunities may therefore reduce investment and direct resources towards share repurchases.

\section{Conclusion}

Literature on the impact of share repurchases on investment policy has shown that executives are willing to compromise long-term growth for short-term gains using share repurchases. Especially in South Africa, the translation of corporate profitability into societal welfare is a contentious topic. With share repurchases potentially having an impact on long-term growth - and the effect thereof on employment a study of the relationship of share repurchases on corporate investment policies is of specific relevance in this country.

With share repurchases being a relatively under-researched area in South Africa, mainly owing to the absence of comprehensive share repurchase data, this study has attempted to grow the body of knowledge on share repurchases in South Africa, with particular focus on its effect on investment policy. 
In ascertaining the impact of share repurchases on investment policy, three proxies for investment were identified from literature, namely employment (based on number of employees, and salaries and wages), capital investment (CAPEX) and research and development (R\&D). As the nonavailability of growth opportunities can directly affect a company's decision to partake in share repurchases, four proxies for growth opportunities (cash flow, $\mathrm{Q}$ ratio, D/P ratio and CAPEX/PPE ratio) were applied to control for growth opportunities.

A panel regression analysis was applied to test the relationship between share repurchases and the investment outcome variables. The panel regression results showed a significant positive relationship between share repurchases and $R \& D$. These results contrast with existing empirical evidence, reporting significant negative relationships between share repurchases and investment outcomes.

The results of this study therefore indicate that, when growth opportunities are available, share repurchases do not negatively affect investment policies of South African corporates. Johannesburg Stock Exchange-listed companies that enter into share repurchases show increased investment in $R \& D$ activities, which may indicate that increased $R \& D$ expenses are regarded as a necessity to remain competitive in a range of advanced technological industries.

The practical application of these results is that South African share repurchases should not be discouraged, because companies repurchasing shares also increase their investment for future growth. The policy implication is that South African share repurchase regulations differ from global practice, which may affect the assessment of investment behaviour of companies that enter into share repurchases.

Contradictory to global evidence, South African share repurchases have a positive effect on corporate investment policies. Investment and share repurchase behaviour may well be country-specific.

\section{Recommendations}

It is recommended that future studies on JSE-listed companies address a longer share repurchase period and also address the possible endogeneity issues pertaining to the identification of unobservable growth opportunities. Performing similar studies in other developing countries and in non-US developed countries will also indicate whether differing regulatory environments affect the results.

It is also recommended that regulatory bodies in South Africa address the opaqueness of share repurchase information by revisiting the $3 \%$ announcement rule on open market share repurchases. In-time share repurchase announcements will equip all stakeholders to make informed decisions - and will assist researchers and company stakeholders to assess effectively the impact of share repurchases on corporate investment policies.

\section{Acknowledgements Competing interests}

The authors declare that they have no financial or personal relationship which may have inappropriately influenced them in writing this article.

\section{Authors' contributions}

N.W. was responsible for the research design and supervision; M.J.B. was responsible for data gathering and data analysis; while both authors contributed equally towards report writing.

\section{Funding information}

This research received no specific grant from any funding agency in the public, commercial or not-for-profit sectors.

\section{Data availability statement}

Data sharing is not applicable to this article as no new data were created or analysed in this study.

\section{Disclaimer}

The views and opinions expressed in this article are those of the authors and do not necessarily reflect the official policy or position of any affiliated agency of the authors.

\section{References}

Adam, T. \& Goyal, V.K., 2008, 'The investment opportunity set and its proxy variables', The Journal of Financial Research 31(1), 41-63. https://doi.org/10.1111/j.1475 6803.2008.00231.x

Almeida, H., Fos, V. \& Kronlund, M., 2016, 'The real effects of share repurchases', Journal of Financial Economics 119(1), 168-185. https://doi.org/10.1016/j. jfineco.2015.08.008

Balachandran, B., Chalmers, K. \& Haman, J., 2008, 'On-market share buybacks, exercisable share options and earnings management', Accounting and Finance 48(1), 25-49. https://doi.org/10.1111/j.1467-629X.2007.00230.x

Balcilar, M., Gupta, R., Jooste, C. \& Wohar, M.E., 2016, 'Periodically collapsing bubbles in the South African stock market', Research in International Business and Finance 38(C), 191-201. https://doi.org/10.1016/j.ribaf.2016.04.010

Bender, R. \& Ward, K., 2008, Corporate Financial Strategy, Routledge, London.

Bester, P.G., 2008, 'Shareholder distribution choices for industrial companies listed on the JSE: Share buybacks versus dividends', Unpublished MBA research report, University of Stellenbosch Business School, University of Stellenbosch.

Bester, P.G., Wesson, N. \& Hamman, W.D., 2010, 'Share buy-backs for a selection of JSE-listed companies: An exploratory study', South African Journal of Business Management 41(4), 47-58. https://doi.org/10.4102/sajbm.v41i4.529

Bhana, N., 2007, 'The market reaction to open market share repurchases announcements: The South African experience', Investment Analysts Journal 65, 25-36. https://doi.org/10.1080/10293523.2007.11082486

Bradford De Long, J. \& Summers, L.H., 1991, 'Equipment investment and economic growth', Quarterly Journal of Economics 106(2), 445-502. https://doi.org/ $10.2307 / 2937944$

Bretell, K., Gaffen, D. \& Rohde, D., 2015, How the cult of shareholder value has reshaped corporate America, viewed 20 January 2016, from http://www.reuters. com/investigates/special-report/usa-buybacks-cannibalized/.

Chan, K., Ikenberry, D., Lee, I. \& Wang, Y., 2010, 'Share repurchases as a tool to mislead investors', Journal of Corporate Finance 16(1), 137-158. https://doi.org/10.1016/j. jcorpfin.2009.10.003

Chivaka, R., Siddle, A., Bayne, L., Cairney, C. \& Shev, J., 2009, 'Reasons for share repurchases in South Africa: Theory versus practice', South African Journal of Accounting Research 23(1), 1-30. https://doi.org/10.1080/10291954.2009. 11435137

Chung, K. \& Charoenwong, C., 1991, 'Investment options, assets in place, and the risks of stocks', Financial Management 20(3), 21-33. https://doi.org/10.2307/ 3665748 
Danbolt, J., Hirst, I.R.C. \& Jones, E., 2011, 'The growth opportunities puzzle: Can growth opportunities measures predict firm growth?', European Journal of growth opportunities measures predict firm growth?, Europeed
Finance 17(1), 1-25. https://doi.org/10.1080/13518470903448432

Dittmar, A., 2008, 'Corporate cash policy and how to manage it with stock repurchases', Journal of Applied Corporate Finance 20(3), 22-34. https://doi.org/10.1111/j. 1745-6622.2008.00191.x

Dybvig, P.H. \& Warachka, M. 2015, Tobin's Q does not measure firm performance: Theory, empirics, and alternatives, Working paper, University of San Diego, San Diego, CA.

Evans, J.P. \& Gentry, J.A., 2003, 'Using Tobin's Q ratio to assess the strategy of repurchasing shares', Finance India 17(1), 149-163.

Fenn, G.W. \& Liang, N., 2001, 'Corporate payout policy and managerial stock incentives', Journal of Financial Economics 60(1), 45-72. https://doi.org/10.1016/ S0304-405X(01)00039-3

Fortuin, E., 2015, An exploratory study to determine the extent of share repurchase activity in the South African Banking and Financial Services sectors (1999-2014), Unpublished research report, University of Stellenbosch Business School, University of Stellenbosch.

Frank, M.Z. \& Goyal, V.K., 2009, 'Capital structure decisions: Which factors are reliably important?', Financial Management 38(1), 1-37. https://doi.org/10.1111/j.1755053X.2009.01026.X

Garofalo, P., 2011, Companies lay off workers while spending billions on share buybacks to enrich executives, viewed 10 September 2016, from https://thinkprogress.org/ companies-lay-off-workers-while-spending-billions-on-share-buybacks-to-enrichexecutives.

Grullon, G. \& Michaely, R., 2004, 'The information content of share repurchase programs', Journal of Finance 59(2), 651-680. https://doi.org/10.1111/j.1540programs', Journal
$6261.2004 .00645 . x$

Gul, F., 1998, 'Growth opportunities, capital structure and dividend policies in Japan' Journal of Corporate Finance 5(2), 141-168. https://doi.org/10.1016/S09291199(99)00003-6

Gumport, M., 2007, Data: Comparing stock buybacks (\#5) - Plus Symantec case study, M.G. Holdings/SIP Corporate Advisors, New York.

Harrison, J. \& Freeman, R., 1999, 'Stakeholders, social responsibility, and performance: Empirical evidence and theoretical perspectives', Academy of Management 42(5), 479-485. https://doi.org/10.2307/256971

Hillman, A.J. \& Keim, G.D., 2001, 'Shareholder value, stakeholder management, and social issues: What's the bottom line?', Strategic Management Journal 22(2) 125-139. https://doi.org/10.1002/1097-0266(200101)22:2\%3C125::AID-SMJ150\% 3E3.0.CO;2-

Howe, K.M., He, J. \& Kao, G.W., 1992, 'One-time cash flow announcements and free cash-flow theory: Share repurchases and special dividends', Journal of Finance 47(5), 1963-1975. https://doi.org/10.1111/j.1540-6261.1992.tb04691.x

Hribar, P., Jenkins, N.T. \& Johnson, W.B., 2006, 'Stock repurchases as an earnings management device', Journal of Accounting and Economics 41(1/2), 3-27. https:// doi.org/10.1016/j.jacceco.2005.10.002

Ikenberry, D., Lakonishok, L. \& Vermaelen, T., 1995, 'Market underreaction to open market share repurchases', Journal of Financial Economics 39(2-3), 181-208. https://doi.org/10.1016/0304-405X(95)00826-Z

Jagannathan, M., Stephens, C. \& Weisbach, M.S., 2000, 'Financial flexibility and the choice between dividends and stock repurchases', Journal of Financial Economics 57(3), 355-384. https://doi.org/10.1016/S0304-405X(00)00061-1

Johnson, S., 2003, 'Debt maturity and the effects of growth opportunities and liquidity risk on leverage', The Review of Financial Studies 16(1), 209-236. https://doi. org/10.1093/rfs/16.1.0209

Kim, J., Schremper, R. \& Varaiya, N., 2004, 'Open market repurchase regulations: A cross-country examination', Unpublished MBA dissertation, San Diego State University, San Diego, CA.

Kodongo, O. \& Ojah, K., 2016, 'Does infrastructure really explain economic growth in Sub-Saharan Africa?', Review of Development Finance 6(2), 105-125. https://doi. org/10.1016/j.rdf.2016.12.001

Lagoarde-Segot, T., 2017, 'Financialization: Towards a new research agenda', International Review of Financial Analysis 51(2017), 113-123. https://doi. org/10.1016/j.irfa.2016.03.007
Lazonick, W., 2014, 'Profits without prosperity', Harvard Business Review 92(9), 46-55.

Manconi, A., Peyer, U. \& Vermaelen, T., 2014, Are buybacks good for long-term shareholder value? Evidence from buybacks around the world, Finance Working Paper No. 436/2014, European Corporate Governance Institute, Washington, DC. https://doi.org/10.2139/ssrn.2330807

Mauboussin, M., 2006, Mauboussin on strategy, viewed 10 September 2016, from https://hurricanecapital.files.wordpress.com/2015/02/clear-thinking-aboutshare-repurchase.pdf.

Ottoo, R., 2000, Valuation of corporate growth opportunities - A real options approach, Garland Publishing, New York.

Rappaport, A., 2006, 'Ten ways to create shareholder value', Harvard Business Review 84(9), 66-77.

Richard, M. \& Wilson, C., 2012, Strategic Marketing Management, Routledge, London.

Ro, S., 2014, The rate of share buybacks has doubled the last decade, viewed 26 January 2016, from http://www.businessinsider.com/sp-500-stock-buybackhistory-2014-4.

Stonham, P., 2002, 'A game plan for share repurchases', European Management Journal 20(1), 37-44. https://doi.org/10.1016/S0263-2373(01)00112-8

Sualehkhattak, M. \& Hussain, C.H.M., 2017, 'Do growth opportunities influence the relationship of capital structure, dividend policy and ownership structure with firm value: Empirical evidence of KSE?', Journal of Accounting and Marketing 6(1) 1-11. https://doi.org/10.4172/2168-9601.1000216

Tabtieng, N., 2013, 'Motivations for share repurchase programs and the effect of share prices on managerial decisions to end share repurchase programs in Thailand', International Journal of Business and Social Science 4(10), 257-266.

Turco, E.M., 2018, 'Are stock buybacks crowding out real investment? Empirical evidence from U.S. firms', Dissertation, University of Amsterdam, Amsterdam.

UI Haq, I., 2012, Creating real value, viewed 26 January 2016, from https://www. london.edu/faculty-and-research/lbsr/creating-real-value\#.Vqfk-ip95dg.

Van de Ven, L.L., 2016, 'Share repurchases and the effects on investment behaviour', MSc dissertation, Erasmus School of Economics, Erasmus Universiteit, Rotterdam.

Van Rixtel, A. \& Villegas, A., 2015, 'Equity issuance and share buybacks', Bank of International Settlements Quarterly Review, March(2015), 28-29.

Vermeulen, M. \& Yaffar, Y., 2014, 'Consolidation of the number of treasury shares: The South African experience', South African Journal of Business Management 45(1), 67-77. https://doi.org/10.4102/sajbm.v45i1.118

Wansley, J.W., Lane, W.R. \& Sarkar, S., 1989, 'Managements' view on share repurchase and tender offer premium', Financial Management 18(3), 97-110. https://doi. org/10.2307/3665652

Wesson, N., 2015, 'An empirical model of choice between share repurchases and dividends for companies in selected JSE-listed sectors', Unpublished PhD thesis, University of Stellenbosch, Stellenbosch.

Wesson, N., Bruwer, B.W. \& Hamman, W.D., 2015, 'Share repurchase and dividend payout behaviour: The South African experience', South African Journal of Business Management 46(3), 43-54. https://doi.org/10.4102/sajbm.v46i3.100

Wesson, N., Muller, C. \& Ward, M., 2014, 'Market underreaction to open market share repurchases on the JSE', South African Journal of Business Management 45(4), 59-69. https://doi.org/10.4102/sajbm.v45i4.141

Wesson, N., Muller, C. \& Ward, M., 2017, 'Market reaction to tender and private offers on the JSE', South African Journal of Business Management 48(4), 1-11. https:// doi.org/10.4102/sajbm.v48i4.38

Wesson, N., Smit, E.V.D.M., Kidd, M. \& Hamman, W.D., 2018, 'Determinants of the choice between share repurchases and dividend payments', Research in International Business and Finance 45(0), 180-196. https://doi.org/10.1016/j. ribaf.2017.07.150

White, H., 1984, 'A heteroscedasticity-consistent covariance matrix and a direct test for heteroscedasticity', Econometrica 48(4), 817-838. https://doi.org/10.2307/ 1912934

World Bank, 2014, World development indicators 2014, viewed 10 September 2016 , from http://data.worldbank.org/indicator.

Wrońska-Bukalska, E., Kaźmierska-Jóźwiak, B. \& Rozkovec, J., 2018. 'The information content of share repurchases - Evidence from Poland', E+M Ekonomie Management 21(2), 172-185. https://doi.org/10.15240/tul/001/2018-2-012 


\section{Appendix 1}

TABLE 1-A1: Summary of data sources of variables.

\begin{tabular}{|c|c|c|}
\hline Associated variable & Collected data & Data source \\
\hline \multicolumn{3}{|l|}{ Panel A: Investment policy variables } \\
\hline \multirow[t]{4}{*}{ Capital investment } & Fixed assets acquired $\dagger$ & IRESS, line item 719 \\
\hline & Increase in investments † & IRESS, line item 720 \\
\hline & $\begin{array}{l}\text { Net investment in subsidiaries and } \\
\text { businesses } \dagger\end{array}$ & IRESS, line item 721 \\
\hline & Other related expenses $\dagger$ & IRESS, line item 722 \\
\hline Employment in rand value & Salaries and wages & IRESS, line item 765 \\
\hline Employment in number of employees & Number of employees & IRESS, line item 781 \\
\hline Research and development & Research and development & IRESS, line item 303 \\
\hline \multicolumn{3}{|c|}{ Panel B Control variables for growth opportunities } \\
\hline \multirow[t]{2}{*}{ Cash flow } & Net profit after tax & IRESS, line item 100 \\
\hline & Depreciation & IRESS, line item 088 \\
\hline \multirow[t]{2}{*}{ Q } & Book value of assets & IRESS, line item 051 \\
\hline & Book value of equity & IRESS, line item 013 \\
\hline \multirow[t]{2}{*}{ MBE } & Book value of equity & IRESS, line item 013 \\
\hline & Market capitalisation & IRESS (product price data) \\
\hline \multirow[t]{2}{*}{$\mathrm{D} / \mathrm{P}$} & Total dividends paid & Data captured from annual report, as per methodology applied in the Wesson et al. (2015) study \\
\hline & Market capitalisation & IRESS (product price data) \\
\hline \multirow[t]{3}{*}{ EVF } & Book value of equity & IRESS, line item 013 \\
\hline & Book value of liabilities & IRESS, line item 022 \\
\hline & Market capitalisation & IRESS (product price data) \\
\hline \multirow[t]{2}{*}{ EVE } & Book value of equity & IRESS, line item 013 \\
\hline & Market capitalisation & IRESS (product price data) \\
\hline \multirow[t]{2}{*}{ PPE } & Total book value of land and buildings & IRESS, line item 258 \\
\hline & Total book value of other fixed assets & IRESS, line item 252 \\
\hline
\end{tabular}

$\dagger$, These IRESS data lines were added to represent capital investment.

$M B E$, market-to-book equity; EVF, excess value of the firm; EVE, excess value of equity; PPE, property, plant and equipment; $D / P$, dividend payout ratio; $Q$, Tobin's $Q$.

\section{Appendix 2}

TABLE 1-A2: Descriptive statistics on study population.

\begin{tabular}{lcccc}
\hline Variable & Mean & Median & $\begin{array}{c}\text { Standard } \\
\text { deviation }\end{array}$ & $\begin{array}{c}\text { Number of } \\
\text { observations }\end{array}$ \\
\hline Share repurchases (ratio-level) & 1.318 & 1.721 & 0.592 & 353 \\
Employment (number of employees) & 0.252 & 0.120 & 0.849 & 179 \\
Employment (salaries and wages) & 7.628 & 7.628 & 9.557 & 221 \\
CAPEX & 3.562 & 1.991 & 14.352 & 304 \\
R\&D & 2.649 & 1.610 & 6.784 & 64 \\
Cash flow & 0.305 & 0.031 & 1.090 & 351 \\
Q ratio & 0.165 & 0.160 & 0.097 & 353 \\
MBE ratio & 1.481 & 1.364 & 0.630 & 353 \\
D/P ratio & 2.088 & 1.718 & 1.458 & 353 \\
EVF (\%) & 0.037 & 0.035 & 0.027 & 353 \\
EVE (\%) & 19.510 & 26.700 & 36.574 & 353 \\
CAPEX/PPE ratio & 19.963 & 41.941 & 71.274 & 333 \\
\hline
\end{tabular}

R\&D, research and development; $M B E$, market-to-book equity; D/P, dividend payout ratio EVF, excess value of the firm; EVE, excess value of equity; PPE, property, plant and equipment; CAPEX, capital investment. 